\title{
DATA CONCERNING THE ORIGIN OF THE WHITE RINGS IN THE CORNEA*
}

\author{
BY \\ O. HALMAY \\ From the Department of Ophthalmology, Szombathely County Hospital, Hungary
}

IN spite of the fact that the changes in the cornea, which are referred to in the English literature as "white rings" (in German weisse Ringe), are not a common finding and are not of major importance, a relatively large number of papers has been published on this condition by well-known ophthalmologists, the first to describe and name it being Coats in 1912. Before presenting data concerning the cause of this change it is perhaps worth recalling the principal characteristic of the lesion.

\section{Morphology}

The rings are usually unilateral, though Coats (1913), Kuan (1936), Hesse (1943), and Lisch (1944) described bilateral cases. All authors agree that the rings are subepithelial; this is confirmed by the fact that they do not stain with fluorescein. They usually originate in Bowman's membrane and in rare cases extend into the uppermost layer of the substantia propria. The rings are usually from $0.3 \mathrm{~mm}$. to $1.0 \mathrm{~mm}$. in diameter and can be seen only by slit-lamp examination. They are usually circular, but may be shaped like a kidney, bean, or a pear. The changes are often formed by irregular heaps of granules. Frequently the rings are open at one or more points. With the slit-lamp it can sometimes be seen that the granules located centrally lie deeper than the peripheral granules. Similarly, the larger dots sometimes appear deeper than the smaller ones. In the interior of the rings in some cases irregular arrangements of dust-like granules can be seen.

Opinions vary regarding the nature of the dots constituting the rings, but the majority of authors consider them to be due to hyaline degeneration; some, however, consider the cause to be fatty degeneration. Miller and Gordon (1950) suggest that calcium is present in the deposits.

The lesions are most commonly situated at the lower segment of the cornea, but we have found them in all parts of the cornea not covered by the upper lid. This point may be of importance in considering the aetiology.

\section{Aetiology}

Opinions on the aetiology of the lesions fall into three main groups: (1) Congenital. (2) Secondary to intra-ocular disease. (3) Trauma.

(1) Congenital.-The theory was put forward by Coats (1912), and later by Mayou (1933), Kuan (1936), and Faldi (1950), but it is based only on hypothesis. Faldi's 
view that the lesions may be due to the incomplete absorption of the superficial fibres of the "anterior vitreous" in the 11 to $13 \mathrm{~mm}$. embryo has not been supported by later authors. Further, his views are based on observations in a single case.

(2) Secondary to Intra-ocular Disease.-The best-known representative of this view is Ballantyne (1933), who described four cases in detail. Since in one patient he found the white rings associated with acute exudative chorioiditis, in the second with acute glaucoma, and in the third with chorioido-retinitis, he came to the conclusion that a metabolic substance produced by degeneration in these diseases could have been responsible for their development. This hypothesis may have seemed obvious in the circumstances, but it is worth noting the last sentence of his description of his first patient, a 43-year-old engine-driver: "In the course of his occupation he often got 'fires' in his eyes".

A paper on a further four cases was published in 1939 by Bietti, the first author in the Italian literature on this subject; he holds the same view. He obtained a history of injury in one patient only; the other three had iridocyclitis, so he considered that the corneal changes were the result of a metabolic process disturbed by inflammation.

(3) Trauma.-The supporters of this aetiology are Macrae (1935), Uyama (1936), Kraupa (1938), Purtscher (1949), Miller and Gordon (1950), and, in particular, Hesse (1943), who described the condition in a series of 43 patients, 79 per cent. of them men and only 21 per cent. women. An important finding was that 40 per cent. of the patients were employed by the state railway and immediately before the observation, like the engine-driver patient of Ballantyne (1933), had sparks in their eyes.

From these data Hesse (1943) concluded that foreign bodies in the eye might have played the most important role in causing the corneal change and, in particular, that hot sparks in contact with the cornea for a short time had caused superficial burning. The author explains the ring-shape frequently seen by the fact that coagulation can occur in Bowman's membrane round the hot foreign body. These lipoid-like or hyaline-like granules must be considered to be the consequence of tissue coagulation, and they constitute the true "white rings".

The case of Miller and Gordon (1950) deserves attention because they observed white rings in the cornea of a patient whose eye had to be enucleated because of choroidal sarcoma. In spite of the fact that their case was one of intra-ocular disease, they did not consider this to be the cause, unlike Ballantyne (1933) and Bietti (1939), but attributed the white rings to injury received in the explosion of a carbide installation thirty years before.

In addition to these authors there are others who do not give an opinion as to the aetiology of the condition-Stallard (1934) for instance, who gives a detailed description of one case.

In the case described by Ziporkes (1936), the patient was struck in the right eye with the edge of a plant $[s i c]$ one week before she was seen. The author saw a typical white ring in this eye, but did not venture to attribute this to the injury.

\section{Case Reports}

Since June, 1961, we have had the opportunity of observing white rings in the cornea in 14 patients (13 male and 1 female), and to simplify the presentation of these, details have been set out in the Table opposite. 
TABLE

DETAILS OF 14 CASES OF WHITE RINGS IN THE CORNEA

\begin{tabular}{|c|c|c|c|c|c|c|}
\hline \multirow{2}{*}{$\begin{array}{l}\text { Case } \\
\text { No. }\end{array}$} & \multirow[b]{2}{*}{ Sex } & \multirow[b]{2}{*}{$\begin{array}{l}\text { Age } \\
\text { Yrs }\end{array}$} & \multirow[b]{2}{*}{ Profession } & \multicolumn{2}{|c|}{ Localization } & \multirow[b]{2}{*}{ Comment } \\
\hline & & & & $\begin{array}{l}\text { Right } \\
\text { Eye }\end{array}$ & $\begin{array}{l}\text { Left } \\
\text { Eye }\end{array}$ & \\
\hline 1 & $\mathbf{M}$ & 41 & Locksmith & & & $\begin{array}{l}\text { Sent with mycosis corneae to our } \\
\text { department. See text }\end{array}$ \\
\hline 2 & $\mathbf{M}$ & 49 & Stoker & & & $\begin{array}{l}\text { In connexion with slit-lamp } \\
\text { examination for other reasons }\end{array}$ \\
\hline 3 & $\mathbf{M}$ & 37 & Coupler & & & See text \\
\hline 4 & $\mathbf{M}$ & 33 & Coupler & & & $\begin{array}{l}\text { Extraction of foreign body from the } \\
\text { other part of the same cornea }\end{array}$ \\
\hline 5 & $\mathrm{~F}$ & 42 & Housewife & & & $\begin{array}{l}\text { Feeling of foreign body being present } \\
\text { without there being one. } \\
\text { Only female patient }\end{array}$ \\
\hline 6 & $\mathbf{M}$ & 22 & Locksmith & & & $\begin{array}{l}\text { Discovered in connexion with } \\
\text { epidemic keratoconjunctivitis }\end{array}$ \\
\hline 7 & $\mathbf{M}$ & 29 & Welder & & & $\begin{array}{l}\text { Extraction of foreign body from the } \\
\text { other eye }\end{array}$ \\
\hline 8 & $\mathbf{M}$ & 38 & $\begin{array}{l}\text { Engine- } \\
\text { driver }\end{array}$ & & & $\begin{array}{l}\text { Two days previously had a spark in } \\
\text { the eye; since then, stinging pain }\end{array}$ \\
\hline 9 & $\mathbf{M}$ & 30 & Stoker & & & See text \\
\hline 10 & $\mathbf{M}$ & 53 & $\begin{array}{l}\text { Engine- } \\
\text { driver }\end{array}$ & & & $\begin{array}{l}\text { Extraction of foreign body from the } \\
\text { other part of the same cornea }\end{array}$ \\
\hline 11 & $\mathbf{M}$ & 27 & Locksmith & & & $\begin{array}{l}\text { In connexion with slit-lamp } \\
\text { examination for other reasons }\end{array}$ \\
\hline 12 & $\mathbf{M}$ & 64 & Stoker & & & $\begin{array}{l}\text { Feeling of foreign body being present } \\
\text { without there being one }\end{array}$ \\
\hline 13 & $\mathbf{M}$ & 53 & $\begin{array}{l}\text { Road- } \\
\text { mender }\end{array}$ & & & See text \\
\hline 14 & $\mathbf{M}$ & 36 & $\begin{array}{l}\text { Ticket- } \\
\text { inspector }\end{array}$ & & & $\begin{array}{l}\text { One day previously had a spark in } \\
\text { the eye }\end{array}$ \\
\hline
\end{tabular}




\section{Discussion}

It is a striking fact that 93 per cent. of the patients in this series are men and they form the majority in all the other series quoted. Of Hesse's 43 patients 79 per cent. were men and of Kuan's 11 patients 82 per cent. were men. Ballantyne (1933), Bietti (1939), Purtscher (1949), and Sármány (1962) each cite 4 cases fully and in all 16 of them the proportion of men was 75 per cent. All 4 cases of Baskaynak (1962) and all 3 cases of Coats (1913) were in men.

The most characteristic fact in our series, however, is that 85 per cent. of our patients were railway employees, all but two being employed by the Szombathely directorate of railways or in the engine repair shop. This is very significant in view of the fact that railway employees represent altogether only 2.2 per cent. of the entire population of the county.

Purtscher (1949) shares Hesse's (1943) opinion that in the evolution of the white rings trauma is the most important factor. It is supported by the fact that in 75 per cent. of his patients the alterations were caused by sparks from a locomotive.

The soundness of the argument in favour of a traumatic origin is demonstrated best by examining the localization of the white rings described in the published cases. It can be well shown by Sármány's (1962) illustration supplemented by my own cases (Fig. 1). They show clearly that without exception the rings occur in those parts of the cornea that are not covered by the upper lid. If the origin were congenital or intra-ocular they would also be likely to occur at 11-1 o'clock near the limbus. As these parts of the cornea are normally covered by the upper lid they are inaccessible to foreign bodies such as cinders.

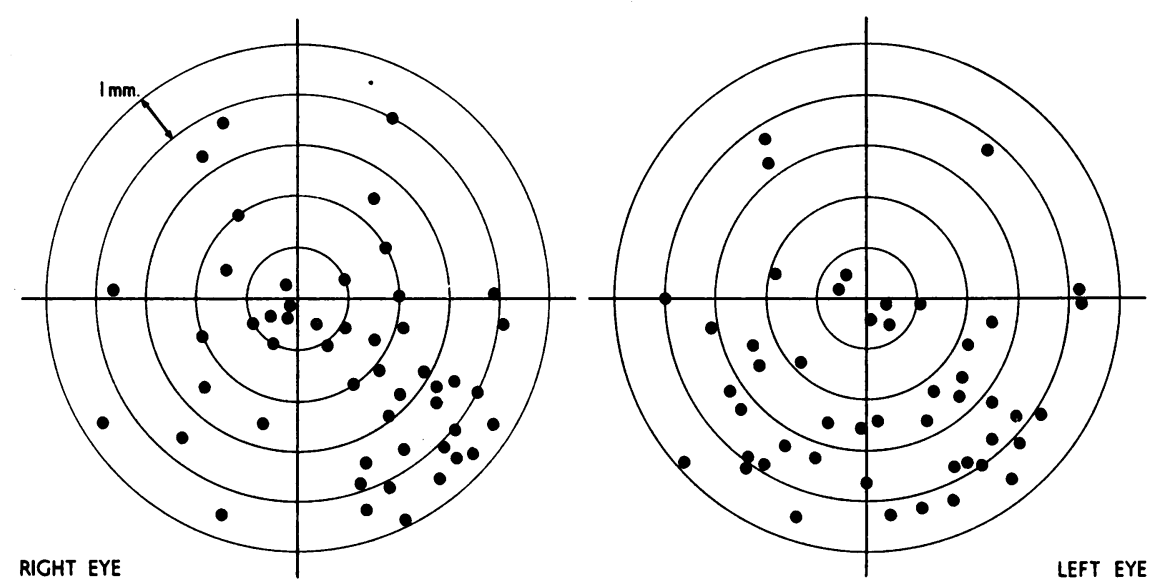

FIG. 1.-Localization of white rings in the cornea described in published cases (collected by Sármány and completed by Halmay).

There is also another fact that, in our opinion, renders unlikely an aetiology based on intra-ocular disease processes, namely, that every year we treat about 1,400 patients in our department of 60 beds, and during eight years we have not observed white rings as incidental findings.

Many authors are of the opinion that these changes are incidental findings and that they are stationary. Undoubtedly Ziporkes (1936) is right when he asserts that there are many more cases with white rings which remain undiagnosed, and that the 
majority of them are detected only by chance on slit-lamp examination performed for some other purpose. Whether the alterations are always stationary cannot be determined. We ourselves saw cases-as did Purtscher (1949)—where one part of the ring or the whole ring disappeared, leaving a fine spot behind. This occurred in our first case, in which the temporal ring totally disappeared and the external half of the other one was found to have been absorbed two and a half years later.

While the relationship of intra-ocular processes to these changes may in some cases seem obvious, as is presumed by Ballantyne (1933), and Bietti (1939), it is difficult to imagine that they have a congenital origin. In this connexion I should like to quote our case No. 9. This 30-year-old stoker was admitted on many occasions to our department with bilateral keratoconjunctivitis eczematosa. On his last admission we were surprised to see a typical white ring in his left cornea (see Table). As we had not seen this on previous occasions, it is evident that the rings appeared during the period between his last two admissions. Considering his occupation there seems every likelihood that this was the cause.

The problem of the length of time needed for the white rings to develop from the time of injury is not easy to solve. I do not think anyone has had the opportunity of making an exact observation. Case No. 3 got a spark from the locomotive in his right eye during a journey; half an hour later at the out-patient department of a little country hospital the investigating doctor, using a hand magnifying glass, observed two white "foreign bodies". As he was unable to get them out he sent the patient to our department by ambulance. With the slit-lamp we observed two typical white

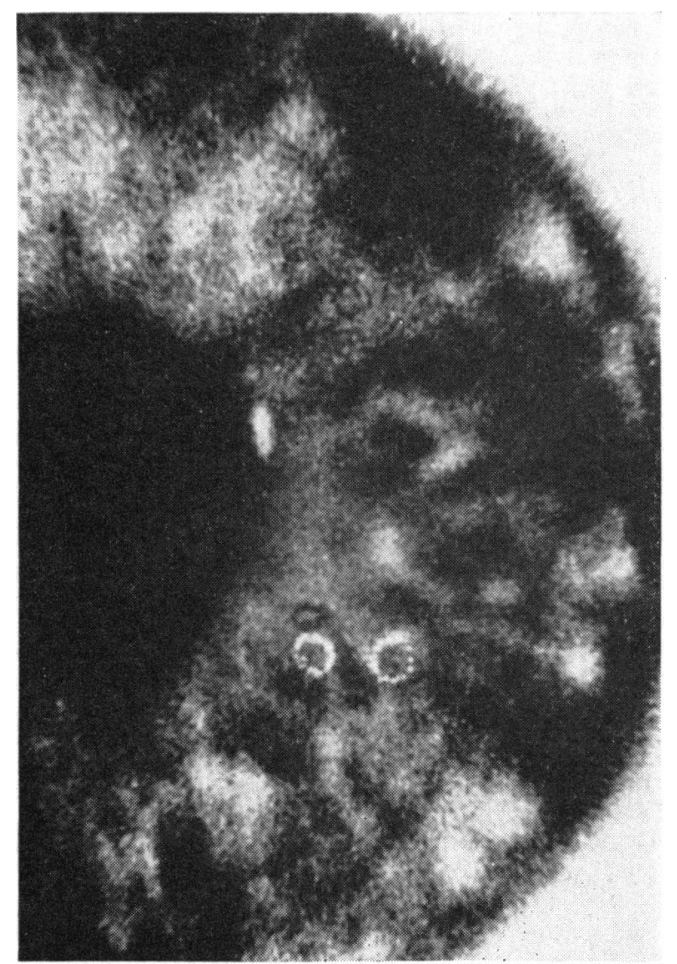

FIG. 2.-Case No. 3. Two typical white rings lying subepithelially in the right eye. 
rings lying subepithelially (Fig. 2). Three hours and a half had passed from the time of the injury to our observation. As we did not find any foreign body we have to suppose that the alterations, seen by the doctor who referred the patient half an hour after injury, corresponded to the white rings. We have no reason to doubt that the greyish-white granules composing the rings were formed immediately after the burn.

Case No. 13, a road-mender, is noteworthy as the only man in the series who was not a railway employee. Four years ago during his work he knocked a stone against his right eye. A traumatic cataract developed for which he was operated on shortly after the accident. He was admitted to our department three years later for an operation on a secondary cataract. On slit-lamp examination it appeared that he had a white ring in the cornea of his injured eye (see Table). Considering that he had not complained about his eyes-apart from the above-mentioned injury-we may suppose that trauma had a role in the development of the white ring in his case too.

Although we consider that there is little doubt of the traumatic origin of the rings there are two factors for which we have so far not been able to find an explanation. Why is the epithelium undamaged, appearing intact at ordinary magnifications, although this layer of the cornea is the first to be affected by the insult? (The granules, however, are always deposited subepithelially.) Why are the changes ring-shaped, when one might expect to find diffuse, macula-like coagulation after the burn? There are presumably other factors which we are still unable to explain.

\section{Summary}

White rings in the cornea were seen in 14 patients over three years. The 13 male patients were, with one exception, railwaymen or ironworkers. From this the author concludes that Hesse (1943) and Purtscher (1949) are right in believing that traumatic factors, in particular hot sparks and metal foreign bodies, play a decisive role in the development of this corneal change.

\section{REFERENCES}

Ballantyne, A. J. (1933). Brit. J. Ophthal., 17, 336.

BASKAYNAK, K. (1962). Ophthal. Lit., 16, 1093.

BiETti, G. B. (1939). Boll. Ocul., 18, 907.

CoATs, G. (1912). Trans. ophthal. Soc. U.K., 32, 52.

- (1913). Proc. roy. Soc. Med., 7, 3.

FALdI, S. (1950). G. ital. Oftal., 3, 146.

Hesse, E. (1943). von Graefes Arch. Ophthal., 145, 253.

KraUPA, E. (1938). Ophthalmologica (Basel), 96, 34.

KuAN, K. P. (1936). von Graefes Arch. Ophthal., 135, 135.

LISCH, K. (1944). Ibid., 147, 145.

MACRAE, A. (1935). Trans. ophthal. Soc. U.K., 55, 545.

MaYOU, M. S. (1933). Brit. J. Ophthal., 17, 342.

Miller, S. J. H., and Gordon, W. H. (1950). Ibid., 34, 176

Purtscher, E. (1949). von Graefes Arch. Ophthal., 149, 397.

SÁRMÁNY, J. (1962). Szemészet, 99, 237.

Stallard, H. B. (1934). Brit. J. Ophthal., 18, 452.

Uyama, Y. (1936). Arch. Ophthal., 15, 309.

ZIPORKES, J. (1936). Ibid., 15, 112. 